\title{
Tunable and rotatable birefringence controller based on electrical control of liquid crystal filled photonic bandgap fibers
}

\author{
Wei, Lei; Alkeskjold, Thomas Tanggaard; Bjarklev, Anders Overgaard
}

\section{Published in:}

Conference abstract series, CLEO/Europe - EQEC

Link to article, DOI:

10.1109/CLEOE-EQEC.2009.5191502

Publication date:

2009

Document Version

Publisher's PDF, also known as Version of record

Link back to DTU Orbit

Citation (APA):

Wei, L., Alkeskjold, T. T., \& Bjarklev, A. O. (2009). Tunable and rotatable birefringence controller based on electrical control of liquid crystal filled photonic bandgap fibers. In Conference abstract series, CLEO/Europe EQEC (pp. 1-1). IEEE. https://doi.org/10.1109/CLEOE-EQEC.2009.5191502

\section{General rights}

Copyright and moral rights for the publications made accessible in the public portal are retained by the authors and/or other copyright owners and it is a condition of accessing publications that users recognise and abide by the legal requirements associated with these rights.

- Users may download and print one copy of any publication from the public portal for the purpose of private study or research.

- You may not further distribute the material or use it for any profit-making activity or commercial gain

- You may freely distribute the URL identifying the publication in the public portal 


\title{
Tunable and Rotatable Birefringence Controller Based on Electrical Control of Liquid Crystal Filled Photonic Bandgap Fibers
}

\author{
L. Wei ${ }^{l}$, T. T. Alkeskjold ${ }^{2}$, A. Bjarklev ${ }^{l}$ \\ 1. DTU Fotonik, Department of Photonics Engineering, Technical University of Denmark, DK-2800 Lyngby, Denmark \\ 2. Crystal Fibre A/S, Blokken 84, DK-3460 Birkerød, Denmark
}

Continuously tunable birefringence controllers by using Liquid Crystal Photonic BandGap (LCPBG) fibers have been proposed [1,2]. Here, we demonstrate the first compact electrically tunable and rotatable birefringence controller based on LCPBG fibers. The cross section of the device is shown in Fig. 1(a). A LCPBG fiber is mounted between two v-grooves fabricated in a silicon substrate by standard UV lithography and KOH wet etching. $200 \mathrm{~nm}$ gold electrodes are deposited on the side walls of the grooves, forming a set of electrodes, which fix the fiber at four orthogonal corners relative to the core. The device electrodes are connected in different electrode configurations (ECs) corresponding to three directions of the electric field $\left(0^{\circ}, 45^{\circ}\right.$, and $\left.90^{\circ}\right)$ :

EC1 $\left(0^{\circ}\right)$ : electrode $1=\mathrm{Vs}$, electrode $4=-\mathrm{Vs}$, electrode $2=$ electrode $3=$ ground

EC2 $\left(45^{\circ}\right)$ : electrode $1=$ electrode $2=0.707 \mathrm{Vs}$, electrode $3=$ electrode $4=-0.707 \mathrm{Vs}$.

EC3 $\left(90^{\circ}\right)$ : electrode $2=\mathrm{Vs}$, electrode $3=-\mathrm{Vs}$, electrode $1=$ electrode $4=$ ground.

At $25^{\circ} \mathrm{C}$, a birefringence change of $7.37 \times 10^{-5}$ is obtained by applying $210 \mathrm{Vrms}$ with $\mathrm{EC} 1$ connection at $1520 \mathrm{~nm}$. More birefringence changes shown in Fig. 1(b) are observed when an input signal with a longer wavelength is launched, e.g. a change in birefringence of $8.13 \times 10^{-5}, 8.55 \times 10^{-5}$ and $8.94 \times 10^{-5}$ are obtained for $1550 \mathrm{~nm}, 1580 \mathrm{~nm}$ and $1600 \mathrm{~nm}$, respectively. With the rotatable electric field, the absolute changes in birefringence in the wavelength range 1520nm-1600nm are shown in Fig. 1(c) for EC2 and Fig. 1(d) for EC3. The changes in birefringence are less than that of EC1, since the electric field to the fiber breaks the cylindrical symmetry of the LC alignment and subsequently induces a polarization dependence of the transmission.

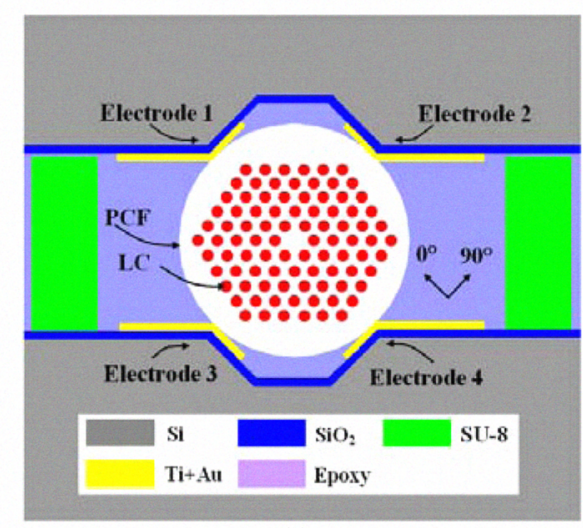

(a)

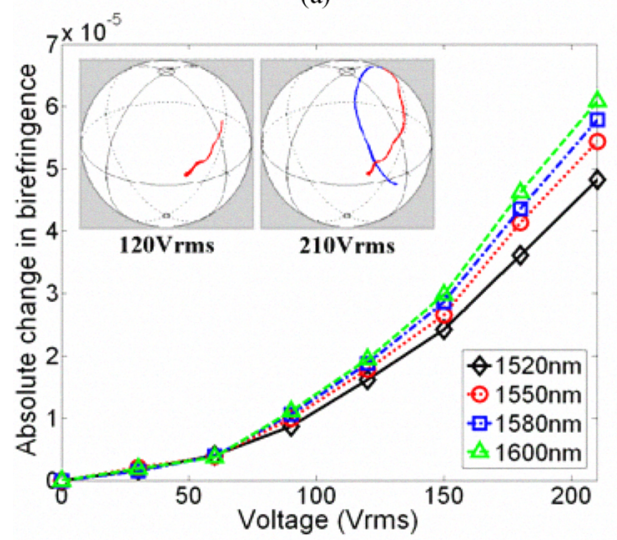

(c)

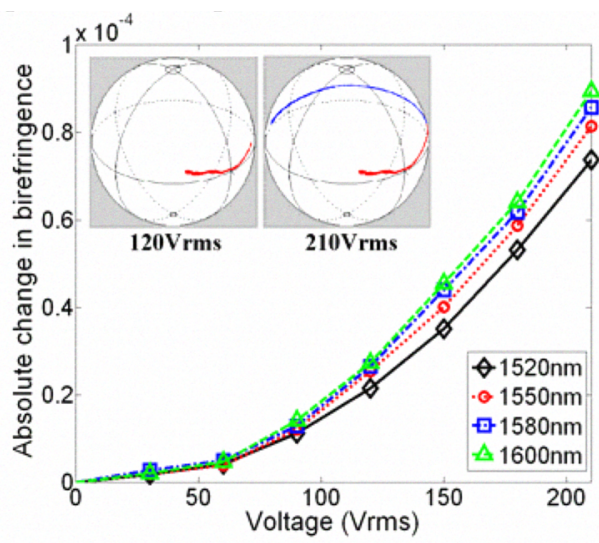

(b)

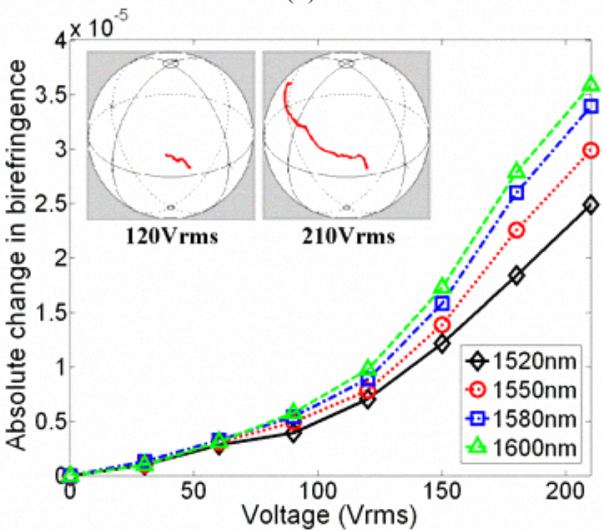

(d)

Fig. I (a). The cross section of the LCPBG tiber device. Electrically induced absolute change in biretringence of this LCPBG device in the wavelength range $1520 \mathrm{~nm}-1600 \mathrm{~nm}$ for EC1 (b), EC2 (c) and EC3 (d). The insets shows the phase shift on the Poincaré sphere with a driving voltage of $120 \mathrm{Vrms}$ and $210 \mathrm{Vrms}$ at $1550 \mathrm{~nm}$ for EC1 (b), EC2 (c) and EC3 (d).

\section{References}

[1] L. Scolari, T. T. Alkeskjold, J. Riishede, A. Bjarklev, D. S. Hermann, A. Anawati, M. D. Nielsen, and P. Bassi, "Continuously tunable devices based on electrical control of dual-frequency liquid crystal filled photonic bandgap fibers," Opt. Express 13, 7483-7496, (2005). [2] L. Wei, L. Eskildsen, J. Weirich, L. Scolari, T. T. Alkeskjold, and A. Bjarklev, "Continuously tunable all-in-fiber devices based on thermal and electrical control of negative dielectric anisotropy liquid crystal photonic bandgap fibers," Appl. Opt. 48, 497-503 (2009) 